\title{
JOURNAL.RU
}

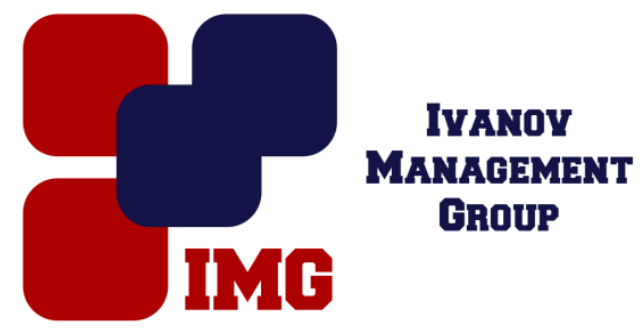

Джалилова М.А.

Российский сочииальный государственный университет РГСУ Москва, Россия

doi: $10.18411 / \mathrm{jj}-31-07-2017-40$

idsp 000001:1j-31-07-2017-40

\section{Предпосылки появления пенитенциарной системы в России}

\section{Аннотация}

Статья представляет собой анализ предпосылок появления пенитенциарной системы в России. Помимо этого, произведена попытка исследовать, каким именно образом это происходило. Для данной цели были исследованы некоторые памятники права, а также исторические события, являющиеся базисом любых социальных, следовательно, и правовых, институтов.

Ключевые слова: пенитенциарная система, тюрьма, Соборное Уложение, наказание, средства принуждения, исполнение наказания.

Наиболее общее учение об исполнении наказания начало зарождаться еще в конце XVIII века и, в первую очередь, было связано с исследованиями Дж. Говарда и И. Бентама, направленными на гуманизацию тюремной системы. Еще в те далекие годы понимали, сколь важен данный вопрос для нормального существования общества, а так же самих заключенных.

К сожалению, на современном этапе развития для Российской Федерации, чьи тюрьмы переполнены, это является крайне болезненным вопросом. Несмотря на то, что число заключенных снизилось с 1990-х гг., а их условия жизни стали ближе к мировым стандартам, все же совершенно очевидно, что стране необходимы коренные реформы в данной области. 
В связи с этим будет достаточно любопытно взглянуть на самые первые предпосылки появления пенитенциарной системы в России. Ведь, современность всегда не более, чем отражение истории.

Как средство принуждения, тюрьмы в Русском государстве появляются довольно рано. Так в Двинской судной грамоте 1397 года указано на тюремное заключение лиц, «окованных в железа» [1]. Но существует не мало оснований думать, что указанная практика появилась несколько раньше, а в XIII-XIV веках лишь получила свое отражение в законодательстве Руси.

При этом, по большей части тюрьма была не столько средством наказания преступников, а местом сохранения их о суда [2]. Не малый вес тюрьма приобретает в системе карательных органов Российского государства, по мере дальнейшего генезиса феодального общества в России.

В связи с этим нельзя не отметить, что одним из главных средств наказания, тюрьма становится уже в XVI веке.

В знаменитом Судебнике 1550 года тюремное заключение занимает значительное место. Судебник предусматривает широкое применение наказаний в виде помещения в тюрьму за взяточничество, ложное обвинение судей в преднамеренном неправосудии. В нем также можно проследить существовании четырех групп (видов) мест заключения.

1) частные тюрьмы, которые расположены при дворах и резиденциях крупных феодалов и князей.

2) государственные тюрьмы.

3) монастыри. Пожалуй, самая удивительная группа для современного человека.

4) места заключения, развитие которых происходило в процессе земско-губных преобразований. Население Московского государства принимало в их развитие достаточно активное участие [3].

В 1556 году параллельно с другими, учреждается должность тюремного сторожа [4].

Система наказаний в этот исторический период несколько усложняется, формируются новые цели наказания - устрашение и изоляция преступников [5]. Роль тюрьмы возрастает больше в XVII веке, в тот момент, когда классовая борьба между крестьянами, нищетой и царской властью достигает апогеи. Так, с 1630 по 1650 г. восстания были совершенны в 30 русских городах [6]. 
Народное недовольство становится стимулом создания нового нормативно-правового акта, способного хоть в какой-то мере регулировать взаимоотношения различных слоев общества.

Заигрывание властей перед народом приодитк тому, что к 1 сентября 1648 года в Москву созываются выборные из «всяких чинов людей» для участия в составлении нового свода законов Руси - Уложения «чтобы то все уложение было прочно и подвижно», а в конце января 1649 года Уложение было уже заключено и затем вскоре напечатано и разослано по России, дабы «всякие дела делать по тому уложению» [7].

Соборное Уложение 1649 года предусматривало тюремное заключение в 40 случаях.

Примечателен тот факт, что указанный вид наказания получает в Уложении довольно подробную регламентацию. Уложению известно бессрочное тюремное заключение (до «государева указа» и «покамест порука будет»), пожизненное тюремное заключение (для разбойников и иных «лихих людей») и тюремное заключение на определенный срок от одного дня до четырех лет. Кроме того, был установлен неопределенный срок тюремного заключения. Тюремное заключение является мерой наказания, предназначенной за совершение довольно широкого круга преступлений. К ним относились:

1) оскорбление чести;

2) подлоги, татьба, разбой;

3) детоубийство;

4) проступки по службе;

5) преступления против государственного управления;

6) кормчество и др. [8]

Иногда тюремное заключение соединялось с различного рода имущественными взысканиями, наказанием батогами, битием кнутом. В некоторых случаях тюремное наказание было сопряжено с «изувечивающими» наказаниями.

Для некоторых групп преступлений оно могло быть заключено в соединении с ссылкой. Ссылка в определенные места, по сути, заменила остракизм.

Ссылка достигает своего полного развития в XVII веке, получая широчайшее применение.

Ссылка для религиозных и политических преступников чаще всего заключалась в помещении виновного в монастырь на территории европейской 
части России с последующим постригом или без такового. Ссылка в Сибирь «на житье на реку Лену» - единственный случай, когда в Уложении указывается конкретное место ссылки, полагалась «московским и городским посадским людям», если они «учнут за кого закладываться и называться чьими крестьянами или людьми» [9]. Ссылке могли подлежать и иные группы лиц: содержатели питейных заведений за нарушение монополии государства на торговлю спиртным; соучастники в краже из жилища, если одним участников совершено убийство и т.д.

Как мы можем видеть, предпосылки появления в России пенитенциарной системы современного типа были заложены достаточно давно. Фактически, данный институт был известен отечественному праву еще со средних веков, что не может не поражать современных исследователей. Помимо этого, наказание было отличным в зависимости от тяжести совершенного преступления; от отношений, на которые было направлено посягательство. Это выдает достаточно высокий уровень развития права на тот исторический период.

***

1. Российское законодательствоX-XX веков. Т 2. Законодательство периода образования и укрепления Русского централизованного государства. М., 1985 г. 520 с.

2. Гогель С. К. Вопросы уголовного права, процесса и тюрьмоведения. СПб, 1906 г. 646 с.

3. Рогов В. А. История уголовного права, террора и репрессий в Русском государстве XVXVIII вв. - М., 1995. 465 с.

4. Исаев И. А. История государства и права России. М., 1996 г. 544 с.

5. Исаев И. А. История государства и права России. М., 1996 г. 544 с.

6. Викторский С. Н. История смертной казни России и современное ее состояние. М., 1912 г. $470 \mathrm{c.}$

7. Викторский С. Н. История смертной казни России и современное ее состояние. М., 1912 Г. $470 \mathrm{c}$.

8. Российское законодательство Х-ХХ вв. Т. 3. Акты земских соборов. М., 1985 г. 512 с.

9. Орлов А. С. Хрестоматия по истории России, Соборное Уложение 1649 г. Гл.ХІХ. 